\title{
PERKEMBANGAN PEMAHAMAN MATEMATIS SISWA SEKOLAH DASAR KELAS V BERDASARKAN TEORI PIRIE-KIEREN PADA TOPIK PECAHAN
}

\author{
Nur Aida Endah Pratama \\ STKIP PGRI Trenggalek \\ Jln. Supriyadi No.22 Ngares Trenggalek \\ Email : aydapratama12@gmail.com.
}

\begin{abstract}
This study is conducted to describe and illustrate the flow of development of mathematical understanding on fifth graders in problem solving of fractions based on the theory suggested by Pirie-Kieren. The qualitative-narrative approach was used to describe clearly, in detail and comprehensively the level of development of students' mathematical understanding with reference to Pirie-Kieren's theory. The results of the analysis found that there are similarities within the flow of understanding developments on fifth graders in problem solving fractions, which starts from the stage of image making, moving towards the image having, then developed at the property level to the level of formalizing noticing. The difference lies in the back folding process that occurs when a less complete understanding at a certain level in the Pirie-Kieren theory.
\end{abstract}

Keywords: mathematical understanding, Pirie-Kieren theory, folding back, elementary school

\begin{abstract}
Abstrak: Penelitian ini bertujuan untuk mendeskripsikan dan menggambarkan alur perkembangan pemahaman matematis siswa sekolah dasar kelas $\mathrm{V}$ dalam menyelesaikan masalah pecahan berdasarkan teori Pirie-Kieren. Pendekatan kualitatif-naratif digunakan untuk memaparkan secara jelas, teperinci dan menyeluruh deskrispsi level perkembangan pemahaman matematis siswa dengan mengacu pada teori Pirie-Kieren. Hasil analisis ditemukan bahwa terdapat kesamaan alur perkembangan pemahaman siswa sekolah dasar kelas $\mathrm{V}$ dalam menyelesaikan masalah pecahan, yaitu dimulai dari tahap image making, bergerak menuju image having, kemudian berkembang pada level property noticing sampai pada level formalizing. Perbedaannya terletak pada proses folding back yang terjadi ketika melengkapi pemahaman yang kurang pada level tertentu dalam teori Pirie-Kieren.
\end{abstract}

Kata kunci: pemahaman matematis, teori Pirie-Kieren, folding back, $S D$

Pemahaman merupakan hal utama yang ingin dicapai dalam pembelajaran. Pada tingkat sekolah dasar, pemahaman dapat dibangun dan dikembangkan melalui pengetahuan faktual (Kemendikbud, 2013). Pengetahuan faktual dimaknai sebagai pengetahuan yang bersumber dari keadaan nyata dan dilakukan dalam kegiatan sehari-hari dengan cara mengamati hal-hal sekitar, kemudian menganalisis dan mem- buat pertanyaan agar dapat dihubungkan dalam pembelajaran.

Matematika merupakan salah satu bidang studi yang mengembangkan pembelajaran melalui pengetahuan faktual. Implikasinya, dalam matematika sering dikenal dengan istilah pembelajaran konstruktivis, yaitu pembelajaran yang dikembangkan berdasarkan pengalaman 
masing-masing siswa, sehingga bersifat aktif, bebas dan unik (Sa'dijah, 2016). Selain itu, dikenal juga pendekatan konstekstual dan pembelajaran matematika realistik yang juga mengusung konsep 'faktual' untuk mengenalkan matematika dalam pembelajaran di sekolah. Sehingga, pembelajaran dengan mengembangkan pengetahuan faktual dianggap menjadi salah satu pembelajaran yang baik (Oers, 2009; Gokalp \& Sharma, 2010).

Pecahan merupakan salah satu konsep matematika yang dapat dibelajarkan dengan menerapkan konsep faktual, yaitu mengaitkan pecahan dengan kegiatan sehari-hari. Hal ini dapat terjadi, karena sebenarnya konsep pecahan sudah didapatkan siswa sebelum secara formal dipelajari di sekolah (Hunting \& Sharpley, 1988). Selain itu, Yoshida (2005) menyatakan bahwa terdapat hubungan yang kuat antara pecahan dalam kehidupan sehari-hari dengan pembelajaran di sekolah. Sehingga, diyakini bahwa konsep pecahan dalam matematika dapat dibangun melalui kegiatan sehari-hari.

Konsep pecahan dalam matematika memiliki banyak keterhubungan dan keberlanjutan dengan pengetahuan sebelumnya maupun sesudahnya (Sieglar, et. al, 2013). Wong \& Evans (2007) menegaskan bahwa pemahaman pecahan merupakan prasyarat yang terhubung dengan konsep lain dalam matematika, yaitu aljabar, pengukuran, rasio dan proporsi (Behr, et. al dalam Razak, dkk, 2012).

Sieglar, et. al (2013) juga menemukan bahwa pengetahuan pecahan yang kurang dalam tahap sekolah dasar dapat memprediksi prestasi matematika dan pengetahuan tentang aljabar dalam tingkat sekolah yang lebih tinggi. Akibatnya, jika siswa belum benar-benar memahami konsep pecahan, maka akan mengalami banyak kesulitan dalam mempelajari konsep lain yang terkait dengan pecahan (Razak, dkk, 2012). Berdasarkan hal tersebut, pecahan ditentukan sebagai materi dalam penelitian, karena keterhubungan dan keberlanjutan antara konsep pecahan, dan keterkaitan konsep pecahan dengan konsep-konsep yang lain berpengaruh pada konstruksi pemahaman matematis siswa.

Konstruksi pemahaman matematis siswa erat kaitannya dengan proses berfikir (Subanji, 2015:15). Dalam penelitian ini, proses siswa mengonstruksi pemahaman merupakan acuan untuk melihat perkembangan pemahaman matematis siswa. Teori Pirie-Kieren digunakan sebagai alat analisis dalam penelitian ini, karena teori ini menyediakan cara untuk menganalisis, mendeskripsikan, serta menghitung perkembangan pemahaman matematis siswa (Martin, 2001a) dari sebuah topik, pada orang tertentu, sepanjang waktu (Pirie \& Kieren, 1994; Pirie \& Martin, 2000; Martin, 2001b; Manu 2005). Sehingga, teori ini sesuai dengan konsep konstruktivis dan faktual yang dijelaskan sebelumnya, bahwa cara mengonstruksi pemahaman setiap individu berbeda, karena informasi yang diperoleh dimaknai sesuai dengan cara berfikir masing-masing individu (Pirie-Kieren, 1994).

Terdapat 8 level yang dideskripsikan dalam teori Pirie-Kieren untuk menggambarkan pemahaman, yaitu primitive knowing, image making, image having, property noticing, formalizing, observing, structuring, dan inventizing (Pirie \& Martin, 2000; Manu, 2005). Kedelapan level teori Pirie-Kieren dinyatakan dalam model 'nested circle' (Gambar 1). Model ini menggambarkan bahwa pemahaman berkembang melalui level yang bertingkat, tetapi tidak linear, bersifat menyeluruh, dan terdapat proses rekursif di dalamnya (Pirie \& Kieren, 1994; Lawan, 2011; Gokalp \& Sharma, 2015).

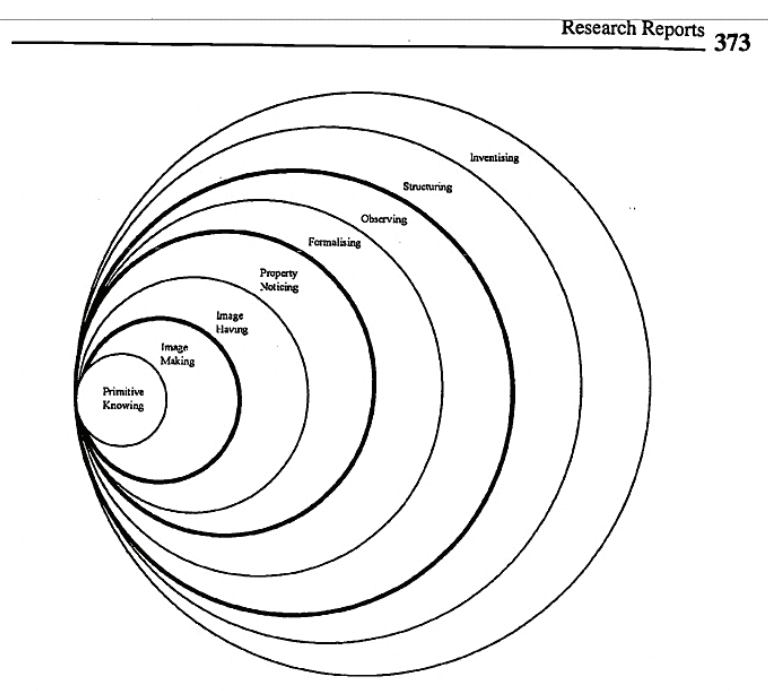

Figure 8. The Pirie-Kieren Model for the Dynamical Growth of

Gambar 1. Model Level Perkembangan Pemahaman Matematis Teori PirieKieren

Level teori Pirie-Kieren dalam penelitian ini tidak seluruhnya digunakan untuk menggambarkan perkembangan pemahaman matematis siswa, melainkan terbatas sampai level formalizing. Hal ini sesuai dengan pendapat Pirie-Kieren (1994) dan beberapa hasil penelitian yang dilakukan oleh Manu 
(2005), Kyriakides (2010) dan Lawan (2011) bahwa perkembangan pemahaman siswa sekolah dasar dapat digambarkan sampai pada level formalizing. Begitupun deksripsi pemahaman pada tiap level dalam penelitian ini, diadaptasi dari Teori Pirie-Kieren (1994), kemudian dikembangkan berdasarkan topik yang digunakan dalam penelitian. Hal ini sesuai dengan hasil analisis Pratama, Sa'dijah, \& Subanji (2016) yang membuktikan bahwa definisi level perkembangan pemahaman dalam teori Pirie-Kieren menjadi kewenangan peneliti untuk mengembangkan sesuai dengan topik yang ditentukan dalam penelitian.

Primitive knowing dalam penelitian ini dimaknai sebagai seluruh pengetahuan terdahulu siswa yang digunakan dalam menyelesaikan masalah pecahan yang diberikan (Pirie \& Martin, 2000; Martin, 2001; Meel, 2003). Image making merupakan tahap siswa mendeskripsikan pecahan sesuai dengan pemikirannya ketika menyelesaikan masalah yang diberikan (Pirie \& Martin, 2000). Image Having dimaknai sebagai tahap siswa ketika sudah mempunyai mental image, yaitu gambaran yang dipunyai siswa ketika mengadaptasi informasi untuk menyelesaikan masalah yang berkaitan dengan pecahan dan bersifat bebas dan tidak terbatas (Pirie-Kieren, 1994; Meel, 2003; Waner \& Schorr, 2004). Property Noticing dimaknai sebagai tahap siswa dalam menerapkan atau menghubungkan sifat-sifat yang diketahui dari penyelesaian soal sebelumnya, kemudian dapat menerapkan untuk menyelesaikan soal berikutnya (Martin, 2001; Meel, 2003; Warner \& Schorr, 2004; Lawan, 2011; Gokalp \& Sharma, 2010; Sengul \& Argat, 2015). Formalizing merupakan tahapan siswa dalam memaknai atau memberikan alasan yang tepat serta dapat menarik kesimpulan atas tindakan yang dilakukan.

Perkembangan pemahaman matematis teori Pirie-Kieren memperbolehkan siswa untuk bergerak maju dan mundur antar layer guna mengumpulkan informasi (Droujkova, et. al, 2005), sehingga disebut tidak linear. Sedangkan tindakan kembali ke layer sebelumnya untuk mengumpulkan informasi dinamakan dengan folding back (Pirie \& Kieren, 1994; Pirie \& Martin, 2000; Kyriakides, 2009). Folding back merupakan keistimewaan dari teori ini karena hasil dari folding back menandakan adanya perluasan pengetahuan yang berarti bahwa terjadi perkembangan dalam konstruksi pemahaman siswa (Lawan, 2011, Pirie \& Martin, 2000); Martin, et. al, 2005, 2005). Proses folding back ini, juga dapat digambarkan dalam model nested circle teori Pirie-Kieren. Sehingga, selain untuk mempertegas perbedaan alur perkembangan pemahaman setiap individu diantara level teori Pirie-Kieren (Sengul \& Argat, 2015), model nested circle juga berfungsi untuk mengidentifikasi terjadinya folding back dalam model yang disajikan.

Berdasarkan hal tersebut di atas, penelitian ini dilakukan untuk mengetahui proses siswa dalam mengonstruksi pemahaman dalam menyelesaikan masalah pecahan, kemudian dianalisis dalam kerangka teori Pirie-Kieren. Jenjang kelas V sekolah dasar ditentukan sebagai kelas penelitian karena materi pecahan pada kelas $\mathrm{V}$ dianggap memuat banyak keterhubungan konsep dan terkait dengan konsep lain dalam matematika. Sehingga, penelitian ini dilakukan dengan tujuan untuk mendeskripsikan dan menggambarkan alur perkembangan pemahaman matematis siswa sekolah dasar kelas V dalam menyelesaikan masalah pecahan berdasarkan teori Pirie-Kieren.

\section{METODE}

Penelitian ini menggunakan pendekatan kualitatif-naratif. Hal ini dikarenakan data dan informasi yang diperoleh dalam penelitian merupakan data kualitatif dan dianalisis secara kualitatif, kemudian dinarasikan secara jelas, terperinci dan menyeluruh. Dalam penelitian, peneliti berperan sebagai instrumen utama penelitian, dan menggunakan instrumen pendukung berupa soal tes pendahuluan, soal tes konstruksi pemahaman, dan juga pedoman wawancara semi-terstruktur. Soal tes pendahuluan digunakan untuk membantu menentukan subjek penelitian, sedangkan soal tes konstruksi pemahaman dan pedoman wawancara semi-terstruktur digunakan untuk mengumpulkan data utama penelitian. Data yang telah terkumpul dianalisis mengikuti tahap analisis data menurut Creswell (2012), kemudian dideskripsikan mengikuti deskripsi level teori PirieKieren sebagai alat analisisnya.

Berikut instrumen pendukung berupa soal tes konstruksi pemahaman yang diberikan pada subjek penelitian. 


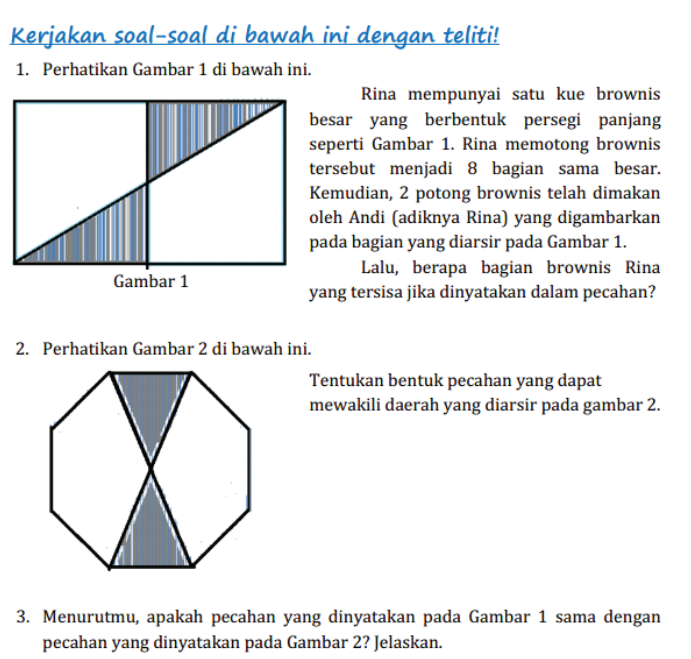

Gambar 2. Soal Tes Konstruksi Pemahaman

Lokasi penelitian bertempat di SDNP 2 Malang dengan subjek penelitian berjumlah 51 siswa yang berasal dari kelas V-B dan V-D. Tes konstruksi pemahaman diberikan kepada 6 subjek terpilih, diwakili oleh 2 subjek kategori tinggi diberi inisial T1 dan T2, 2 subjek kategori sedang diberi inisial $\mathrm{S} 1$ dan S2, dan 2 subjek kategori rendah diberi inisial R1 dan R2. 6 subjek terpilih ini ditentukan berdasarkan pengelompokan hasil tes pendahuluan seluruh subjek, didukung dengan saran guru untuk mengetahui kemampuan berkomunikasi siswa dan verifikasi data berkenaan dengan kesesuaian pengelompokan dalam kategori tinggi, sedang dan rendah. Wawancara semi-terstruktur dilakukan pada 6 subjek terpilih dengan mengacu pada pedoman wawancara semi-terstruktur yang dikembangkan, untuk menggali proses siswa mengonstruksi pemahaman selama mengerjakan tes konstruksi pemahaman. Sehingga, alur penyelesaian tes konstruksi pemahaman 6 subjek terpilih dapat diketahui dengan jelas, kemudian dideskripsikan ke dalam level teori Pirie-Kieren.

\section{HASIL}

Hasil analisis data tes pendahuluan diketahui bahwa siswa yang termasuk dalam kategori rendah cenderung lebih banyak dari pada siswa dalam kategori tinggi dan sedang. Data yang diperoleh dari tes konstruksi pemahaman dan hasil wawancara semi-terstruktur, keduanya saling melengkapi untuk memperoleh informasi tentang proses konstruksi pemahaman siswa. Berdasarkan hasil analisis kedua data, diketahui bahwa alur perkembangan pemahaman siswa kelas V SDNP 2 Malang secara umum mempunyai kesamaan dan perbedaan. Kesamaan terjadi pada perkembangan alur pemahaman, sedangkan perbedaan terlihat dari tindakan folding back yang dilakukan siswa. Secara ringkas, kesamaan dan perbedaan proses konstruksi pemahaman subjek penelitian untuk masing-masing kategori dipaparkan dalam tabel-tabel sebagai berikut.

\section{Deskripsi Proses Konstruksi Pemahaman Subjek T1 dan T2}

Deskripsi proses konstruksi pemahaman subjek T1 dan T2 dapat dilihat pada tabel 1.

Berdasarkan Tabel 1, diketahui kesamaan dan perbedaan alur pemahaman T1 dan T2 dalam menyelesaikan masalah pecahan. Pemahaman T1 dan T2 sama-sama dimulai dari level image making. Pada level image having, T1 dan T2 keduanya sama-sama menentukan operasi pengurangan dengan memperhatikan keterangan pada narasi soal, yaitu kata 'dimakan' yang diketahui dari wawancara. Pada level property noticing, T1 dan T2 dapat menentukaan sebagai bagian utuh dalam pecahan dari keterangan soal. Selain itu, T1 dan T2 dapat menentukan bahwa pecahan merupakan representasi bagian yang dimakan.

Proses folding back yang dilakukan oleh T1 dan T2 terlihat berbeda pada level property noticing untuk melengkapi pemahaman sebelumnya. T1 melengkapi pemahaman pada level primitive knowing tentang letak pembilang dan penyebut pecahan. Sedangkan T2 melakukan folding back pada level primitive knowing sebanyak 3 kali guna mengidentifikasi pola pemotongan yang dibuat untuk melengkapi pemahaman pada level image making. Setelah itu, pemahaman T2 bergerak kembali menuju property noticing. Kemudian, T1 dan T2 keduanya dapat mencapai level formalizing. Walaupun sebelumnya T2 melakukan folding back yaitu melengkapi pemahaman pada level property noticing.

Berdasarkan Tabel 1 di atas, maka alur perkembangan pemahaman T1 dan T2 dapat digambarkan dalam model Pirie-Kieren dapat dilihat pada gambar 3 . 
Tabel 1. Deskripsi Proses Konstruksi Pemahaman Subjek T1 dan T2

\begin{tabular}{|c|c|c|}
\hline $\begin{array}{c}\text { Level } \\
\text { Pirie-Kieren }\end{array}$ & T1 & $\mathbf{T 2}$ \\
\hline Image making & $\begin{array}{l}\text { Mengetahui keterhubungan } \\
\text { gambar dengan narasi sehingga }\end{array}$ & $\begin{array}{l}\text { Mengetahui keterhubungan gambar dan narasi, } \\
\text { tetapi lebih fokus pada narasi. Sehingga }\end{array}$ \\
\hline Image having & $\begin{array}{l}\text { menggambarkan sesuai soal } \\
\text { Memaknai operasi pengurangan dari } 1 \\
\text { bagian yang utuh dengan bagian yan }\end{array}$ & $\begin{array}{l}\text { menggambarkan tidak sesuai soal } \\
\text { kata 'đimakan' dalam narasi, yaitu mengurangkan } \\
\text { g dimakan, yaitu }\end{array}$ \\
\hline Property noticing & $\begin{array}{l}\text { Menghubungkan dan mengkombinasi } \\
\text { sebelumnya tentang bagian yang dipo } \\
\text { Uji pemahaman pada level property } \\
\text { noticing, kemudian melengkapi } \\
\text { pemahaman pada level primitive } \\
\text { knowing. } \\
\text { Tindakan kembali ke level sebelumny }\end{array}$ & $\begin{array}{l}\text { ikan keterangan yang diperoleh dari level } \\
\text { tong dan terdeteksi sebagai bagian utuh pecahan } \\
\text { Melengkapi pemahaman pada level image } \\
\text { making setelah itu baru diuji pemahaman pada } \\
\text { level property noticing. Pemahaman pada level } \\
\text { property noticing belum lengkap, melakukan } 3 \\
\text { kali proses kembali pada level sebelumnya untuk } \\
\text { melengkapi pemahaman. } \\
\text { a sama-sama dibawah arahan. }\end{array}$ \\
\hline Formalizing & $\begin{array}{l}\text { Tanpa disertai dengan kembali pada } \\
\text { level sebelumnya dapat mencapai } \\
\text { formalizing }\end{array}$ & $\begin{array}{l}\text { Melengkapi pemahaman pada level property } \\
\text { noticing baru dapat melengkapi pemahaman } \\
\text { pada level formalizing. }\end{array}$ \\
\hline
\end{tabular}

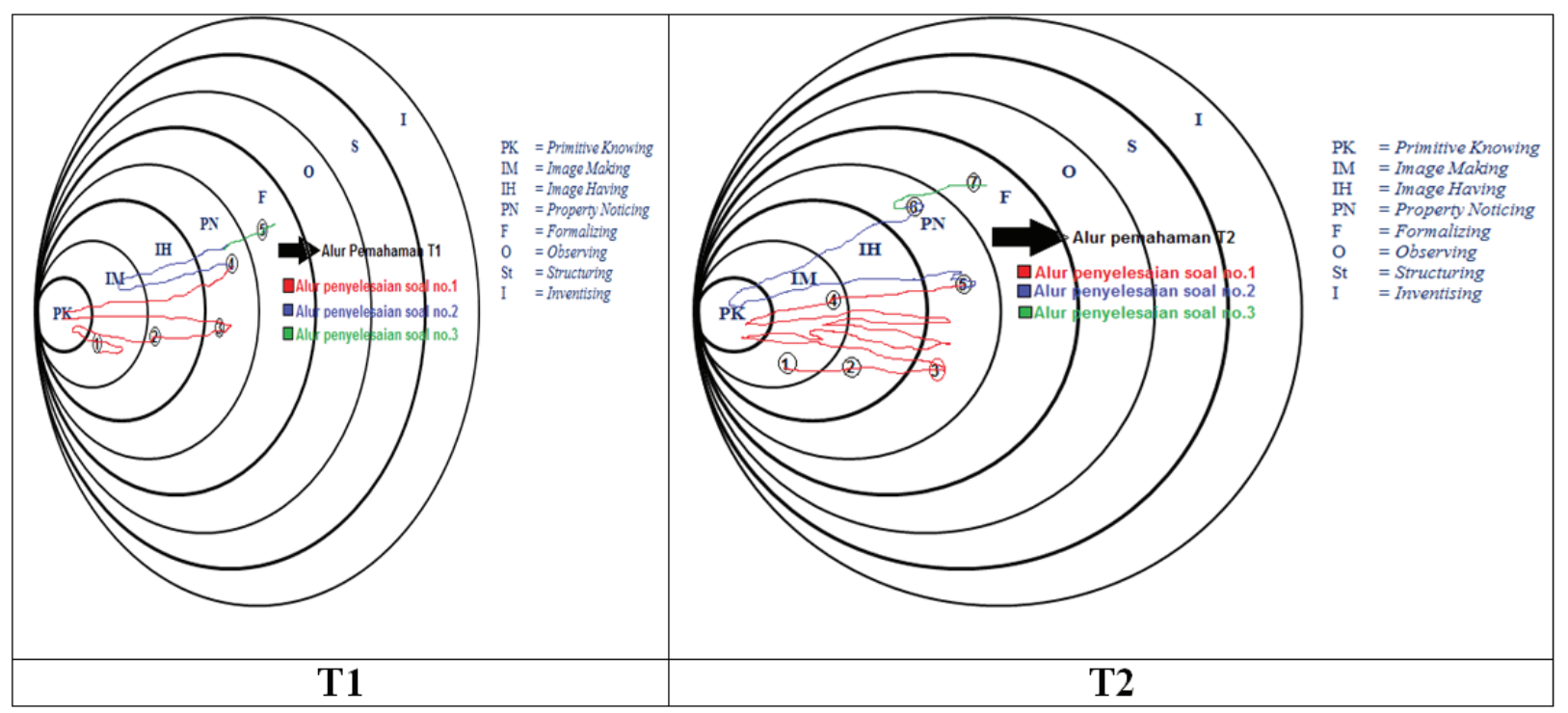

Gambar 3. Alur Perkembangan Pemahaman Matematis T1 dan T2

\section{Deskripsi Proses Konstruksi Pemahaman Subjek S1 dan S2}

Deskripsi proses konstruksi pemahaman subjek S1 dan S2 dapat dilihat pada tabel 2.

Berdasarkan tabel 2, diketahui persamaan dan perbedaan alur pemahaman S1 dan S2 dalam menyelesaikan masalah pecahan. Pemahaman S1 dan S2 sama-sama dimulai dari level image making tetapi kurang sempurna. Hal ini karena pada saat menyelesaikan soal, S1 menyatakan dengan tegas bahwa tidak ada keterhubungan antara Gambar 1 pada soal dengan narasi yang ada untuk menyatakan pecahan. Sedangkan S2 meragukan keterhubungan antara keduanya.

Bergerak pada level image having, S1 dan S2 keduanya sama-sama menentukan operasi pengurangan dengan memperhatikan keterangan pada narasi soal, yaitu kata 'dimakan' yang diketahui dari wawancara. Pada level property noticing, S1 memaknai pengurangan pecahan dengan cara 
Tabel 2. Alur Perkembangan Pemahaman Subjek S1 dan S2

\begin{tabular}{|c|c|c|}
\hline $\begin{array}{c}\text { Level } \\
\text { Pirie-Kieren }\end{array}$ & S1 & $\mathbf{S 2}$ \\
\hline Image making & $\begin{array}{l}\text { menyatakan dengan tegas bahwa tidak } \\
\text { ada keterhubungan antara Gambar } 1 \text { pada } \\
\text { soal dengan narasi untuk menyatakan } \\
\text { pecahan } \\
\text { Gambaran brownis yang menyatakan pecah } \\
\text { dipikirkan } \\
\text { operasi pengurangan dari memperhatikan k }\end{array}$ & $\begin{array}{l}\text { meragukan keterhubungan antara } \\
\text { Gambar } 1 \text { pada soal dengan narasi yang } \\
\text { ada untuk menyatakan pecahan } \\
\text { an digambarkan sesuai dengan apa yang } \\
\text { ata 'dimakan' pada narasi soal }\end{array}$ \\
\hline \multirow[t]{3}{*}{ Property noticing } & $\begin{array}{l}\text { 'Mengurangi' pada pecahan dinyatakan } \\
\text { dengan menghapus bagian }\end{array}$ & $\begin{array}{l}\text { memaknai kata 'dimakan' dalam narasi } \\
\text { dengan pengurangan yang dinyatakan } \\
\text { sebagai ‘bagian yang diambil' dan pada } \\
\text { gambar ditandai dengan arsiran } \\
\text { Utuh pecahan dinyatakan dengan }\end{array}$ \\
\hline & $\begin{array}{l}\text { Proses melengkapi pemahaman pada } \\
\text { level PN dilakukan sebanyak } 3 \text { kali. } \\
\text { Menggunakannya untuk melengkapi } \\
\text { pemahaman pada level IM. Terjadi } \\
\text { inkonsistensi pemaknaan pecahan sbg } \\
\text { hasil bagi dan bagian keseluruhan }\end{array}$ & $\begin{array}{l}\text { Melengkapi pemahaman pada level PN } \\
\text { tanpa adanya arahan. }\end{array}$ \\
\hline & \multicolumn{2}{|c|}{ Menentukan nama bangun datar sesuai jumlah sudut atau sisinya } \\
\hline Formalizing & \multicolumn{2}{|c|}{$\begin{array}{l}\text { Awalnya menyimpulkan pecahan yang diwakili Gambar } 1 \text { dan Gambar } 2 \text { berbeda. } \\
\text { Setelah diberikan arahan keduanya melengkapi pemahaman pada level PN kemudian } \\
\text { menyimpulkan pada level formalizing }\end{array}$} \\
\hline
\end{tabular}

menghapus bagian dalam gambar, sedangkan S2 menandai bagian yang dikurangi dengan arsiran. Dengan demikian, S1 memaknai representasi utuh suatu pecahan dengan, dan S2 menyatakan utuh pecahan dengan .

S1 melakukan folding back pada level sebelumnya sebanyak 3 kali untuk melengkapi pemahaman pada level property noticing yaitu dengan mengidentifikasi kembali gambar representatif dari pecahan yang dibuat. Setelah itu, S1 menggunakan pemahaman pada property noticing untuk melengkapi pemahaman pada level image making. Pada saat hal ini berlangsung, terjadi inkonsistensi pemaknaan pecahan sebagai hasil bagi dan bagian keseluruhan. Di sisi lain, S2 melengkapi pemahaman pada level property noticing tanpa adanya arahan dari peneliti. Setelah itu, pemahaman keduanya mencapai pada level formalizing setelah sebelumnya diberi arahan untuk memperhatikan sifat-sifat pada kedua (Gambar 1 dan Gambar 2) pada soal dan berdasarkan penjelasan S2 tentang perbedaan pecahan dan bukan pecahan.
Berdasarkan pada Tabel 2, maka alur perkembangan pemahaman S1 dan S2 dapat digambarkan dalam model seperti pada Gambar 4.

\section{Deskripsi Proses Konstruksi Pemahaman Subjek R1 dan R2}

Deskripsi proses konstruksi pemahaman subjek R1 dan R2 dapat dilihat pada tabel 3.

Berdasarkan tabel 3, diketahui persamaan dan perbedaan alur pemahaman R1 dan R2 dalam menyelesaikan masalah pecahan. Pemahaman R1 dan R22 sama-sama dimulai dari level image making. Pemahaman R1 termasuk dalam level image making sempurna karena mengetahui keterhubungan gambar dengan narasi sehingga menggambarkan sesuai soal. Sedangkan pemahaman R2 termasuk dalam level image making kurang sempurna, karena menganggap tidak ada keterkaitan antara Gambar 1 dan narasi sehingga gambar yang dibuat tidak sesuai dengan soal.

Bergerak pada level image having, R1 tidak menyatakan bagian yang tersisa dalam bentuk peca- 


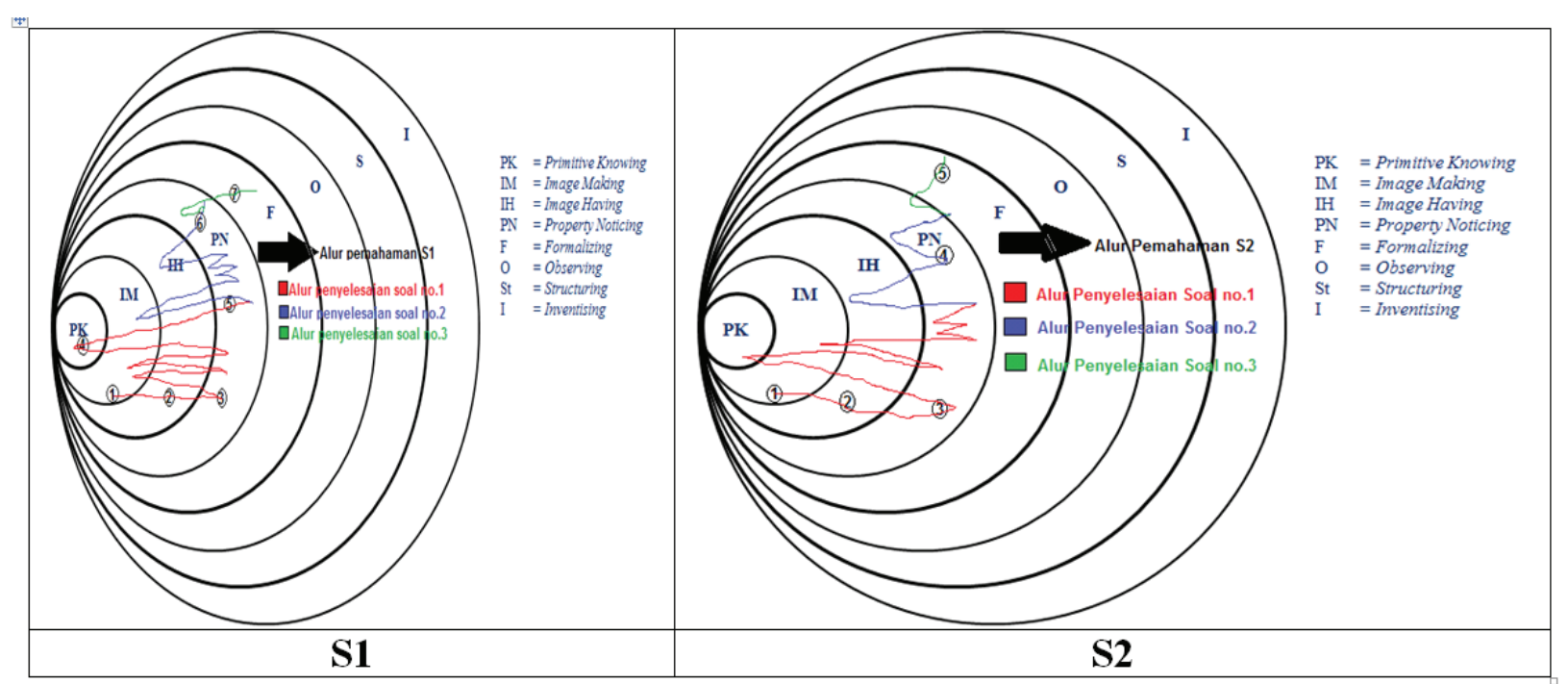

Gambar 4. Alur Perkembangan Pemahaman Matematis S1 dan S2

Tabel 3. Alur Perkembangan Pemahaman Subjek Kategori Rendah

\section{Level}

Pirie-Kieren
R1
R2

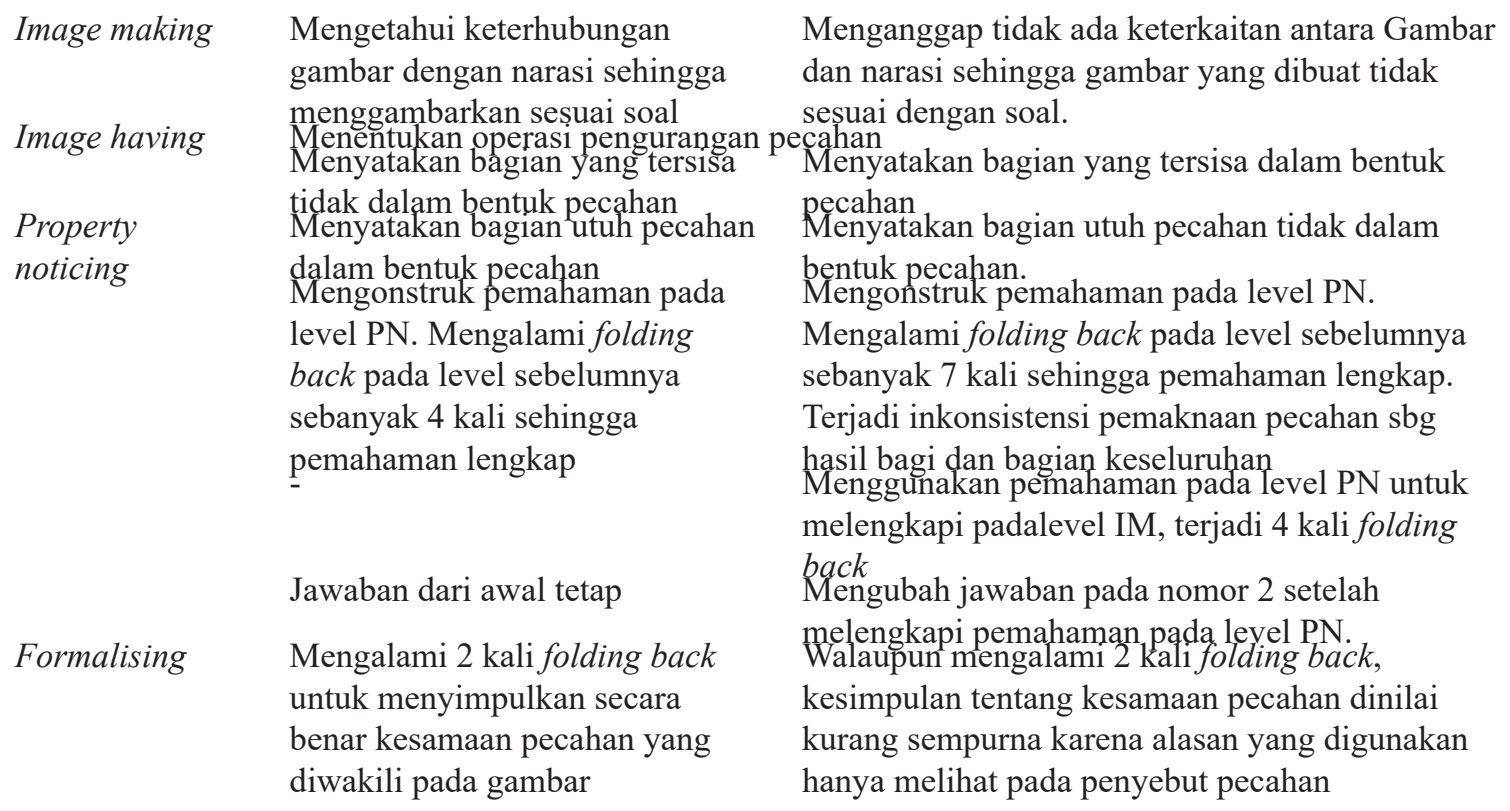

Image making

Mengetahui keterhubungan

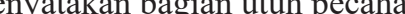
Mengonstruk pemahaman pada level PN. Mengalami folding back pada level sebelumnya ebanyak 4 kali sehingga
Menganggap tidak ada keterkaitan antara Gambar dan narasi sehingga gambar yang dibuat tidak sesuai dengan soal.

bentuk pecahan

Mengonstruk pemahaman pada level PN sebanyak 7 kali sehingga pemahaman lengkap. Terjadi inkonsistensi pemaknaan pecahan sbg

hasil bagi dan bagian keseluruhan melengkapi padalevel IM, terjadi 4 kali folding Mengubah jawaban pada nomor 2 setelah Walaupun pengami 2 padi folding back, kesimpulan tentang kesamaan pecahan dinilai hanya melihat pada penyebut pecahan
Menyatakan bagian yang tersisa dalam bentuk han , tetapi sebaliknya dengan R2. Namun, keduanya dapat menentukan operasi pengurangan dari soal yang disajikan. Pada level property noticing, keduanya dapat menentukan bentuk utuh pecahan tetapi kurang sempurna. R1 mengalami folding back pada level sebelumnya sebanyak 4 kali untuk melengkapi pemahaman pada level property noticing. Sedangkan R2 mengalami folding back pada level sebelumnya sebanyak 7 kali sehingga pemahaman lengkap. Terjadi inkonsistensi pemaknaan pecahan sebagai hasil bagi dan bagian keseluruhan. Pada akhir proses melengkapi pemahaman pada level property noticing, R1 tetap pada jawaban awalnya, namun R2 mengubah jawaban setelah melengkapi pemahamannya. 


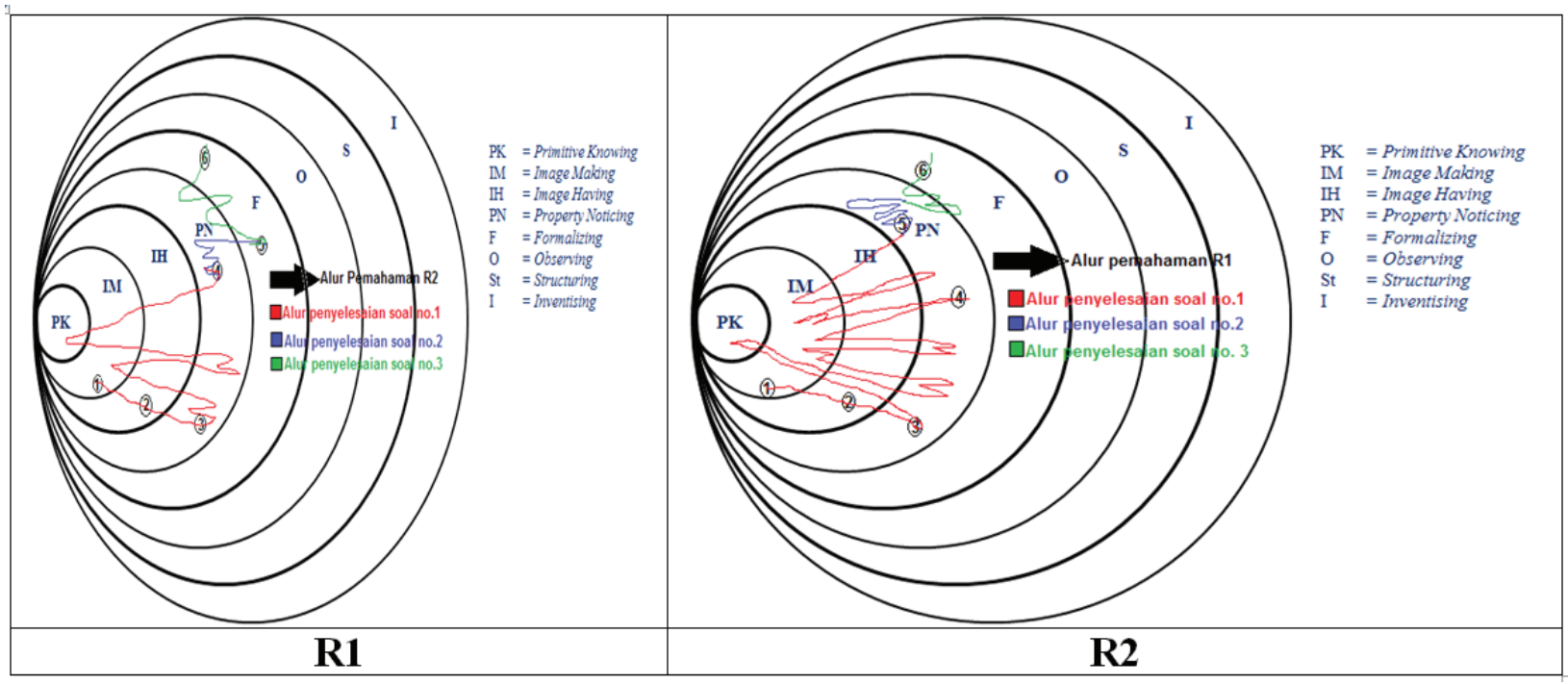

Gambar 5. Alur Perkembangan Pemahaman Matematis R1 dan R2

R1 dan R2 mencapai level formalizing setelah keduanya sama-sama mengalami 2 kali folding back. R1 dapat menyimpulkan secara benar kesamaan pecahan yang diwakili pada gambar. Namun demikain, kesimpulan tentang kesamaan pecahan dinilai kurang sempurna karena alasan yang digunakan hanya melihat pada penyebut pecahan.

Berdasarkan Tabel 3 di atas, maka alur perkembangan pemahaman R1 dan R2 dapat digambarkan dalam model seperti pada Gambar 5.

\section{PEMBAHASAN}

Berdasarkan hasil tes pendahuluan, diketahui bahwa siswa yang tergolong dalam kategori rendah cenderung lebih banyak. Hal ini disebabkan karena pada saat diberikan masalah pecahan, siswa tidak sedang mempelajari materi pecahan yang diujikan di dalam kelas. Selain itu, materi yang berasal dari kelas IV juga turut menjadi salah satu penyebab, karena sudah lama tidak dipelajari kembali oleh siswa. Kedua alasan di atas membuktikan pendapat Hunting (dalam Hunting \& Sharpley, 1988), bahwa terdapat pengaruh lamanya rentang waktu siswa belajar pecahan dengan kemampuan siswa menyelesaikan masalah pecahan.

Paparan data tes konstruksi pemahaman subjek T1, T2, S1, S2, R1, dan R2, dilengkapi dengan wawancara semi-terstruktur diketahui bahwa alur perkembangan pemahaman matematis siswa pada semua kategori sama-sama dimulai dari level image making, bergerak menuju level image having, kemudian level property noticing, sampai pada level formalizing berdasarkan teori Pirie-Kieren. Bedanya, terletak pada alur masing-masing siswa yang berusaha melengkapi pemahaman pada levellevel sebelumnya. Sehingga, pembedanya terletak pada proses folding back, yang merupakan indikasi bahwa perkembangan itu berkembang.

Kesamaan urutan alur perkembangan pemahaman matematis siswa salah satunya disebabkan karena subjek penelitian berada pada tahap kognitif yang sama, yaitu operasional konkret menurut Jean Piaget. Siswa dapat berpikir konkret dan logis berdasarkan kegiatan sehari-hari (Arends, 2004), mengidentifikasi hubungan timbal balik akan suatu hal Fatimah (dalam Sa'diyah, 2016), terlebih mampu menghubungkan dan mengubah unit pecahan dengan baik (Hunting dalam Hunting \& Sharpley, 1988).

Perbedaan proses melengkapi pemahaman disebabkan karena primitive knowing (pemahaman awal) yang dipunyai masing-masing subjek sebelum menyelesaikan masalah pecahan juga berbeda-beda. Selain itu, cara berpikir masing-masing individu dalam mengolah informasi juga berbeda (Pirie \& Kieren, 1994). Perbedaan ini terlihat ketika proses konstruktivis terjadi, dimana siswa berusaha memahami perintah soal kemudian menyelesaikan masalah sesuai yang dipahami, karena dikembangkan berdasarkan pengalaman masing-masing subjek sehingga bersifat bebas, kontekstual dan unik (Sa'dijah, 2016).

Hasil analisis proses perkembangan pemahaman T1, T2, S1, S2, R1 dan R2 diketahui bahwa 
perkembangan pemahaman dimulai dari level image making. Hal ini berkenaan dengan hasil wawancara yang dilakukan, bahwa seluruh subjek menyampaikan apa yang dipikirkan dan dipahami dari maksud soal. Sehingga penyampaian seluruh subjek atas apa yang dipikirkan dalam pikirannya merupakan awal perkembangan sampai pada level image making (Warner \& Schorr, 2004). Selain itu, representasi pecahan yang dinyatakan dengan sebuah brownis berbentuk persegipanjang beserta pola pembagian yang dibuat masing-masing subjek penelitian, digambarkan sebagai gambaran mental dengan mengacu pada apa yang dipahami subjek penelitian. Sehingga, baik tindakan yang menggambarkan pemikiran dalam gambaran mental maupun representasi gambar juga merupakan indikasi bahwa pemahaman T1, T2, S1, S2, R1 dan R2 berada pada level image making (Pirie \& Martin, 2000; Meel, 2003; Martin, 2001b; Martin, et. al, 2005).

Pada level image having, T1, T2, S1, dan S2 menyatakan pengurangan pecahan dari narasi soal dengan memperhatikan kata 'dimakan', sedangkan R1 dan R2 berbeda. R1 menyatakan bagian yang tersisa tidak dalam bentuk pecahan, yaitu 6 bagian tersisa dari 8 keseluruhan dan menjelaskan bahwa menyatakan pengarsiran. R2 menuliskan bagian utuh pecahan tidak dalam bentuk pecahan pula, melainkan hanya dengan 8 bagian. Dengan demikian, terbukti bahwa semua subjek penelitian mempunyai kebebasan untuk membentuk mental image yang tidak terbatas dari apa yang dipahami pada level image having (Meel, 2003; Warner \& Schorr, 2004).

Pada level property noticing, subjek mengonstruksi pemahaman melalui interpretasi bagian keseluruhan pecahan berdasarkan pemahaman pada level sebelumnya. Pada level ini, seluruh subjek berusaha menghubungkan dan mengkombinasikan keterangan yang diperoleh dari level sebelumnya tentang bagian yang dipotong dan terdeteksi sebagai bagian utuh pecahan. Selanjutnya, dikombinasikan dengan pemaknaan atas pengurangan pecahan dari yang dipahami subjek penelitian pada level image having. Tindakan menghubungkan dan mengkombinasikan yang dilakukan T1, T2, S1, S2, R1 dan $\mathrm{R} 2$ termasuk salah satu indikasi bahwa pemahaman berada pada level property noticing (Martin, 2001b; Meel, 2003; Warner \& Schorr, 2004; Lawan, 2011).

Pemahaman subjek pada level property noticing digunakan untuk melengkapi pemahaman pada level image making. Proses ini hampir terjadi pada alur perkembangan pemahaman seluruh subjek penelitian kecuali T1 dan R1. Subjek T2, S1, S2, dan R2 melakukan folding back dari level property noticing, menuju level image making, kembali pada layer primitive knowing dengan urutan yang berbeda-beda pada tiap prosesnya. Selain itu, panjang proses dalam melengkapi pemahaman pada level image making berbeda-beda untuk setiap subjek penelitian.

Seluruh subjek dapat mencapai level formalizing dengan proses yang berbeda. T1 mencapai level formalizing tanpa perlu kembali ke level sebelumnya, sedangan T2, S1, S2, R1 dan R2 harus terlebih dahulu melakukan tindakan folding back dengan disertai arahan oleh peneliti sebelum mencapai level formalizing. T1 mencapai level formalizing dengan memperhatikan jumlah bagian dan besar bagian yang sama ketika diminta menyimpulkan pecahan yang dinyatakan oleh kedua gambar yang berbeda. Sedangkan T2, S1 dan S2 dapat menyimpulkan kembali tentang bentuk pecahan Gambar 1 dan Gambar 2 dengan memperhatikan sifat-sifat pada kedua gambar.

R2 mencapai level formalizing kurang sempurna karena hanya memperhatikan kesamaan pecahan berdasarkan penyebutnya saja, sedangkan pecahan terdiri dari pembilang dan penyebut pecahan. Sehingga, T2, S1, S2, R1 dan R2 dikatakan mencapai level formalizing karena pengetahuan baru yang diperoleh oleh T2, S1, S2, R1 dan R2 berdasarkan perhatiannya pada aturan, sifat-sifat maupun cara yang digunakan untuk menyelesaikan soal yang diberikan (Warner \& Schorr, 2004; Gokalp \& Sharma, 2010). Hal ini sesuai dengan definisi pengetahuan baru pada level formalizing yang diungkapkan oleh Martin (2001b), Meel (2003), Warner \& Schorr (2004), Lawan (2011), Gokalp \& Sharma (2010), Sengul \& Argat (2015) bahwa pengetahun baru dapat dilihat dari cara siswa mengamati sifat-sifat dari topik yang berkaitan.

Berdasarkan pembahasan di atas, seluruh subjek penelitian dapat mencapai level formalizing baik sempurna maupun kurang sempurna dengan adanya arahan. Hal ini sesuai dengan pendapat Pirie \& Kieren (1994) bahwa level formalizing dalam teori Pirie-Kieren dapat dicapai oleh siswa sekolah dasar dibawah bimbingan atau arahan yang diberikan. Selain itu, hasil penelitian Kyriakides (2009) juga menunjukkan bahwa subjek penelitian 
membutuhkan arahan atau intervensi dari peneliti untuk merevisi konstruksi pemahaman pada level formalizing yang kurang benar.

Proses yang dialami siswa untuk mencapai level formalizing sangat panjang dengan alur yang berbeda-beda. Beberapa proses menunjukkan adanya miskonsepsi pemahaman yang dialami oleh subjek penelitian. Miskonsepsi yang terjadi merupakan indikasi siswa mengalami kesulitan untuk memahami konsep-konsep yang terhubung dalam pecahan. Seperti yang ditemukan dalam hasil penelitian Razak, dkk (2012) bahwa banyak kesulitan yang akan dihadapi jika tidak benar-benar memahami tentang pecahan.

Folding back yang dilakukan siswa pada level tertentu terbukti dapat membantu siswa melengkapi pemahaman yang kurang. Hal ini membuktikan bahwa folding back terjadi dengan tujuan untuk memperluas pemahaman yang kurang terhadap masalah yang ditemukan (Pirie \& Martin, 2000); Martin, et. al, 2005), walaupun disisi lain folding back juga akan mencerminkan kurangnya pemahaman siswa dalam memahami konsep pecahan sebagai bagian keseluruhan (Wilson \& Stein, 2007). Urutan proses folding back yang berbeda dari setiap subjek menandakan bahwa cara mengonstruksi pemahaman setiap individu berbeda, karena informasi yang diperoleh dimaknai sesuai dengan cara berfikir masing-masing individu (PirieKieren, 1994), sehingga bersifat bebas, kontekstual dan unik (Sa'dijah, 2016).

\section{SIMPULAN DAN SARAN}

\section{Simpulan}

Hasil analisis diperoleh kesimpulan bahwa alur perkembangan pemahaman siswa sekolah dasar kelas $\mathrm{V}$ dalam menyelesaikan masalah pecahan mempunyai kesamaan, yaitu dimulai dari tahap image making, bergerak menuju image having, kemudian berkembang pada level property noticing sampai pada level formalizing. Perbedaannya terletak pada proses folding back yang terjadi untuk melengkapi pemahaman yang kurang pada levellevel tertentu dalam teori Pirie-Kieren. Deskripsi alur perkembangan pemahaman matematis siswa sekolah dasar kelas $\mathrm{V}$ dalam menyelesaikan masalah pecahan pada tiap level dipaparkan sebagai berikut.

Pada level image making, proses interpretasi pecahan dalam bentuk gambar ditentukan dari cara siswa memaknai keterhubungan narasi dengan gambar pada soal. Pada level image having, kebanyakan subjek menentukan operasi pengurangan pecahan dari kata 'dimakan' dalam narasi, kemudian jumlah yang dikurangi dinyatakan dalam bentuk arsiran. Pada level property noticing, subjek mengonstruksi pemahaman melalui interpretasi bagian keseluruhan pecahan berdasarkan pemahaman pada level sebelumnya. Beberapa subjek menggunakan pemahaman pada level property noticing untuk melengkapi pemahaman pada level image making. Level formalizing dapat dicapai seluruh subjek setelah sebelumnya melengkapi pemahaman pada level property noticing. Sehingga, secara garis besar hasil penelitian ini mendukung pernyataan bahwa folding back merupakan salah satu indikasi pemahaman siswa kelas $\mathrm{V}$ sekolah dasar mengalami perkembangan ketika menyelesaikan masalah pecahan.

\section{Saran}

Berdasarkan hasil penelitian, disarankan bahwa: (1) berkenaan dengan level primitive knowing, sebaiknya guru mengaitkan pembelajaran pecahan yang telah dipelajari pada jenjang sebelumnya, sebelum mulai membelajarkan pecahan pada jenjang kelas V; (2) berkenaan dengan level image making, sebaiknya guru senantiasa menekankan kepada siswa agar lebih teliti dan cermat dalam memperhatikan soal, sebelum memulai menyelesaikan masalah pecahan yang diberikan; (3) berkenaan dengan level imagehaving, guru sebaiknya memantapkan pemahaman konseptual siswa untuk menggambarkan operasi pecahan khususnya pengurangan dalam bentuk gambar. Karena masih terdapat siswa yang mengalami miskonsepsi, yaitu pengurangan pecahan yang direpresentasikan pada gambar yang diartikan dengan menghapus bagian; (4) kaitannya dengan level property noticing, guru sebaiknya juga menekankan kepada siswa untuk memperhatikan ketentuan menggambarkan representasi utuh pecahan pada bentuk gambar; (5) pada level formalizing, guru sebaiknya lebih membiasakan siswa untuk menyimpulkan dengan kalimat sendiri dari apa yang dipelajari selama pembelajaran di dalam kelas.

Bagi peneliti selanjutnya, analisis alur berpikir matematis siswa dapat dikembangkan pada materi lain pada jenjang sekolah dasar. Jika ingin menel- 
iti dengan menggunakan teori yang sama, dapat lebih detail dalam mengkritisi alur perkembangan pemahaman matematis siswa dalam menyelesaikan masalah. Misalnya dengan menambahkan deskrispi yang singkat dan jelas setelah menemukan alur perkembangan pemahaman matematis siswa. Selain itu, dapat pula mengembangkan penelitian dengan mengkaji lebih dalam lagi tentang elemen-elemen pelengkap (complementary elements) yang merupakan bagian dari masing-masing level teori PirieKieren.

\section{DAFTAR RUJUKAN}

Arends, R. I. 2004. Learning to Teach (Sixth Edition). New York: Mc Graw Hill.

Cresswell, J.W. Research Design: Qualitative, Quantitative, and Mixed Methods Approaches. USA: SAGE Publication

Droujkova, M. A., Berenson, S. B, Slaten, K., \& Tombes, S. 2005. A Conceptual Framework For Studying Teacher Preparation : The PirieKieren Model, Collective Understanding, and Methapor. Proceeding of the $29^{\text {th }}$ Conference of the International Group for the Psychology of Mathematics Education. 2:289-296.

Gokalp, D. \& Sharma, D. 2010. A Study on Addition and Subtraction of Fractions : The Use Of PirieKieren Model and Hands-on Activities. Jurnal Procedia Social and Behavioral Science. 2: 5168-5171.

Hunting, R. P., \& Sharpley, C. F. 1988. Fraction Knowledge in Preschool Children. Journal for Research in Mathematics Education, 19(2):175-180.

Kemendikbud. 2013. Kurikulum 2013: Kompetensi Dasar (SD) / Madrasah Ibtidaiyah (MI).

Kyriakides, A. O. 2010. Enganging Everyday Language to Enhance Comprehension Of Fraction Multiplication. Proceeding of CERME 6. January $28^{\text {th }}-$ February First 2009, Lyon France.

Lawan, A. 2011. Growth of Students' Understanding of Part-Whole Sub-Construct of Rational Number on the Layers of Pirie-Kieren Theory. Proceedings of the Seventeenth National Congress of the Association for Mathematics Education of South Africa (AMESA), Vol.1. University of the Witwatersrand Johannesburg.
Manu, S.S. 2005. Growth of Mathematical Understanding in A Bilingual Context: Analysis and Implications. Proceedings of the $29^{\text {th }}$ Conference of the International Group for the Psychology of Mathematics Education. 3:289-296

Martin, L., LaCroix, L., \& Fownes, L. 2005. Folding Back and the Growth of Mathematical Understanding in Workplace Training. ALM International Journal. 1(1):19-35.

Martin, L. C. 2001a. Growing Mathematical Understanding : Teaching and Learning As Listening and Sharing. Proceeding of the Annual Meeting of the North American Chapter of Intenational Group for the Psychology of Mathematics Education 1 and 2. .

Martin, L.C. 2001b. Understanding as a Dynamical Process: How do They get to Where They are? Proceeding of the Annual Meeting of the North American Chapter of Intenational Group for the Psicology of Mathematics Education 1 and 2.

Meel, D. E. 2003. Models and Theories of Mathematical Understanding: Comparing Pirie and Kieren's Model of the Growth of Mathematical Understanding and APOS Theory. CBMS Issues in Mathematical Educations, 12:734-745

Oers, B. E. 2009. Emergent Mathematical Thinking in the Context of Play. Springer: Educ Stud Math (2010) 74 : 23-37.

Pratama, N. A. E., Sa'dijah, C., \& Subanji. 2016. Teori Pirie-Kieren dalam Mendiskripsikan Perkembangan Pemahaman Matematis Siswa. Prosiding Seminar Nasional Pendidikan Dasar 2016 (Peningkatan Kualitas Pendidikan Dasar dalam Menghadapi Daya Saing Regional $(A S E A N))$.

Pirie, S., \& Kieren, T. 1994. Beyond Metaphor: Formalizing in Mathematical Understanding within Constructivist Environments. FLM Publishing Association Vancouver, British Columbia, Canada.

Pirie, S. \& Martin, L. 2000. The Role of collecting in the Growth of Mathematical Understanding. Mathematics Education Research Journal. 12 (2):127-146.

Razak, F. A., Noordin, N., Alias, R., \& Dollah, R. 2012. How Do 13-years Olds in Malaysia Compare Fractions?.Procedia Social and Behavioral Science. 42:100-105. 
Sa'dijah, C. 2016. Pembelajaran Matematika Secara Konstruktivis. Pidato Pengukuhan Jabatan Guru Besar dalam Bidang Ilmu Pendidikan Matematika pada Fakultas Matematika dan Ilmu Pengetahuan Alam. Malang: Universitas Negeri Malang.

Sengul, S., \& Argat, A. 2015. The Analysis of Understanding Factorial concept Processes of $7^{\text {th }}$ Grade Students who have Low Academic Achievement with Pirie Kieren Theory. Jurnal Procedia Social and Behavioral Science. 197: 1263-1270.

Siegler, R. S., Fazio, L. K., Bailey, D. H., \& Zhou, X. 2013. Fractions: The New Frontier for Theories of Numerical Development. Trends in Cognitive Science, 17(1).

Warner, L., \& Schorr, R. Y. 2004. From Primitive

Knowing to Formalizing : The of Student to Student Questioning in the Development of
Mathematical Understanding. Proceeding of the Twenty Sixth Annual Meeting of the North American Chapter of the International Group for Psochology of Mathematics Education: Building Connections between communities. Toronto, Ontario. 2:429-437.

Wilson, P. H., \& Stein, C. C. 2007. The Role of Representations in Growth of Understanding in Pattern-Finding Task. Ninth International Conference Mathematic Education in a Global Community. Charlotte, NC.

Wong, M., \& Evans, D. 2007. Student's Conceptual Understanding of Equivalent Fractions. In J. Watson \& K. Beswick (Eds.), Mathematics: Essesntial Research, essential Practice (Proceedings of the 30th Annual Conference of the Mathematics Education Research Group of Australasia). 2:824-833.

Yoshida, K. 2005. Children's 'Everyday Concepts of Fractions' Based on Vygotsky's Theory: Before and After Fraction Lessons. Proceeding of the $29^{\text {th }}$ Conference of the International Group of the Psychology of Mathematics Education, $1: 334$. 